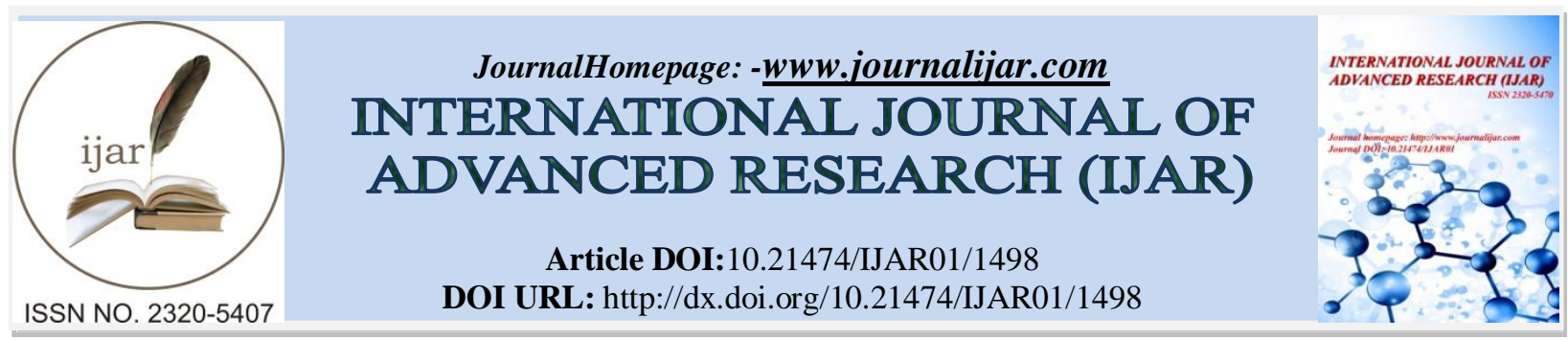

RESEARCH ARTICLE

\title{
TEACHING INNOVATION IN THE TEACHING-LEARNING PROCESS ADMINISTRATION
}

Norberto Pelegrin Entenza, Yurisley Toledo Leal., Maria Rosa Naranjo Llupart.

Universidad Técnica de Manabí, Avenida Universitaria, Urbina y Che Guevara, Portoviejo, Manabí, Ecuador.

\section{Manuscript Info}

Manuscript History

Received: 16 July 2016

Final Accepted: 22 August 2016

Published: September 2016

Key words:-

Innovation, teaching, administration, learning

\section{Abstract}

The research was carried out with the objective to develop a teaching innovation project to update and generate changes in the teachinglearning process of Administration subject of Enterprise Administration Major at the Universidad Técnia de Manabí. Its main contributions were the operational definition of teaching-educative innovation project, the design of a model, its graphic representation and the determination of its premises for administration as a science. In its practical application we got qualitative and quantitative changes in the conception and development of the teaching-learning process, which are shown in the achievement step with the students. We recommend the application of the project in other pedagogic scenarios, evaluate its results and do an investigation to clarify the indicators of the model and an evaluation of its educative and competitiveness pertinence.

Copy Right, IJAR, 2016. All rights reserved.

\section{Introduction:-}

XXI Century is characterized by the constant change, by the demands dealing with competitiveness of educative models, a requirement to guarantee that the knowledge system, skills, values and competencies (to know, to know to do, to know to be and to know to be) link scientifically in a dialectical spiral that allows to integrate and go from known to unknown, for the permanent updating of formation and development of professionals demanded by present society. Otherwise, knowledge becomes obsolete; we demand a permanent education during and for the whole life.

World declaration on higher education in in the XXI C.: vision and action and priority action framework for change and development of higher education, in its article 9. Innovative educative methods: critical thinking and creativity, states:

A. In a fast changing world, we perceive the need of a new vision and a new higher education teaching model that should be centered on the student, which demands, in most countries, deep reforms and a wider access policy to accept more diverse categories of persons and a renovation of contents, methods, practices and knowledge transmission media based on new types of links and collaboration with community and with the wider sectors of society.

B. Highereducationinstitutionsmust educate students to make them well-informed citizens and profoundly motivated, with a critical sense and capable of analyzing society problems, look for their solutions, apply them and assume social responsibilities.

C. To reach these objectives, it could be necessary to reformulate the study plans and use new and adequate methods that would permit to overcome the mere cognitive mastery of disciplines; we should facilitate the 
access to new pedagogical and didactic proposals, and foster them to achieve the acquisition of practical knowledge, competencies and aptitudes for communication, the creative and critical analysis, independent reflection and team work in multicultural contexts, in which creativity demands combining theoretical and traditional practical or local knowledge with advanced science and technology. This restructuration of study plans should take into account men and women differences and the cultural, historical and economic context of each country. The teaching of norms related to human rights and education based on community needs of the whole world should be reflected in the study plans of all disciplines, especially in those which prepare for enterprise activities. The academic staff should play a decisive role in the definition of study plans.

D. The new pedagogical models also suppose new didactic materials. These must be linked to new examination methods that would test not only memory but understanding skills too, the aptitude for practical works and creativity (UNESCO, 1998).

The declaration on higher education in Latin America and the Caribbean, declares: higher education needs to introduce pedagogical methods based on learning to form graduates that learn to learn and to undertake all types of tasks, being able to generate their own jobs and even to create productive entities that contribute to eliminate jobless flagellum. It is necessary to promote the inquiry spirit, for the student to be provided with the tools that would permit the systematic and permanent quest for knowledge, which implies the revision of present pedagogical methods, moving the given emphasis nowadays in the knowledge transmission toward its generation process. In this way students will acquire the tools to learn to learn, to know, to live and to be (UNESCO, 1998).

The Action Plan for the Transformation of Higher Education in Latin America and the Caribbean in the improvement Program of pertinence, in its strategic action lines, states:

Propitiate innovation in the curricula, syllabi, and teaching programs to permit the active participation, the personal transformation and plain potential development of each student.

In the teaching-learning process of Enterprises Administration major at the Universidad Técnica de Manabí, we identify insufficiencies that affect the performance of students and professors, such as:

Development of few projects and competences to learn to undertake;

Predominance of theoretical approaches of contents and experiences to develop innovation teaching the projects transform the professional behaviors, professors and students.

The university substantive processes: teaching, research and link to community, do not integrate adequately from the different disciplines of the curriculum.

The problem situation described, leads us to pose the following scientific problem: How to improve the teachinglearning process of the Administration subject of Enterprises Administration major at the Universidad Técnica de Manabí.

General objective: to develop a teaching innovation project to update and generate changes in the teaching-learning process of the Administration subject of Enterprises Administration major at the Technical University of Manabí.

\section{Development:-}

In the bibliography consulted and the checking of good international practices, we confirmed that there are several definitions on teaching innovation-educative innovation, which center on certain indicators that authors and their institutions of higher education take into consideration. Some have created Teaching Innovation Units with different a conception, that's why it was necessary to build up the operational definition proposed, compass that guides the projection, execution and control of the results exposed in the investigation.

In its presentation Investigation and Educative Innovation refers to the following processes models to generate the educative innovation: investigation and development model, social interaction model, problems resolution model, outstanding the relation between research and educative innovation (Ramirez, 2011). 
Also, among the innovative educative models proposed by the different authors (Garcia and Sanchez, 2014), they point out: problems based learning (PBL), case studies, virtual learning environment, projects based learning, professional competencies based model, cognitive instruction strategy.

Other authors refer, among the innovative educative models, to the reflexive hermeneutic, technicalized efficient, practical artisanal and academical (Garcia and Sanchez, 2014), (Palomo et al., 2011). In the literature consulted on curricular innovation models, author's state: systems model, ecological model, cognitive model, the professor as translator of innovation, dialog model, the change as a critical research-action process, investigation-development model, social interaction model, problems resolution model. The authors present a comparative chart where we can see its characteristics (Martín, 2005), (Universia, 2015), professor's role, advantages and limitations of models, antecedents that allow to assume an eclectic approach for the investigation carried out, trying to center on the advantages declared and minimize its limitations. The proposal of teaching innovation as a result of the present paper focus its educative practices on the dialog model, the change as a critical research-action process and problems resolution without disregarding the contributions of the rest of the models analyzed (Williams, 2013), (Hernández, 2012).

\section{Research Method:-}

For this investigation we assume the proposal of change through process and result as project of teaching or educative innovation, obtained from the correct interrelation of personal components (professor, student, group, family, community and society) and non-personal of the teaching learning process (objectives, contents, methods, media, procedures, individual, frontal and group organization forms and evaluation), where the professor becomes tutor/supervisor and potentiate a more protagonist student. We reach the equilibrium point between theory and practice, it facilitates the professor and student work through the technological advantages applied in educational atmosphere, such as: Internet, virtual learning environment and different useful technological tools for the university study. Through the necessary convergence to a common educative area that recognizes professors and students move, we demand the application of new programs in which the professor must re-elaborate his teaching, research and community link model, making use of innovative technologies and new pedagogical methodologies with the impulse of determined initiatives oriented to professors to stimulate pertinence, quality and university excellence.

It assume the following premises of the teaching innovation project for the teaching learning process of Administration at the Universidad Técnia Manabí: Social, humanistic and universal character of administration, essential for social entities; Triple conception of administration (technique, art and science) from a didactic integrated approach; Integration of administration components as a process (judicial, financial-economic, sociocultural, ethic and environment); Right application of administration principles and functions, in a way to optimize the resources (material, technological financial, human); Entrepreneurship as essential, necessary and permanent quality in the teaching learning process; Systemic integration of the university substantive processes in the subject: formation, research and community link (university-enterprise-society relation); Consideration of the main contributions and limitations of theories and schools of administrative thinking, its evolution; To integrate the New Information and Communications Technologies to the teaching learning process observed in figure 1. 


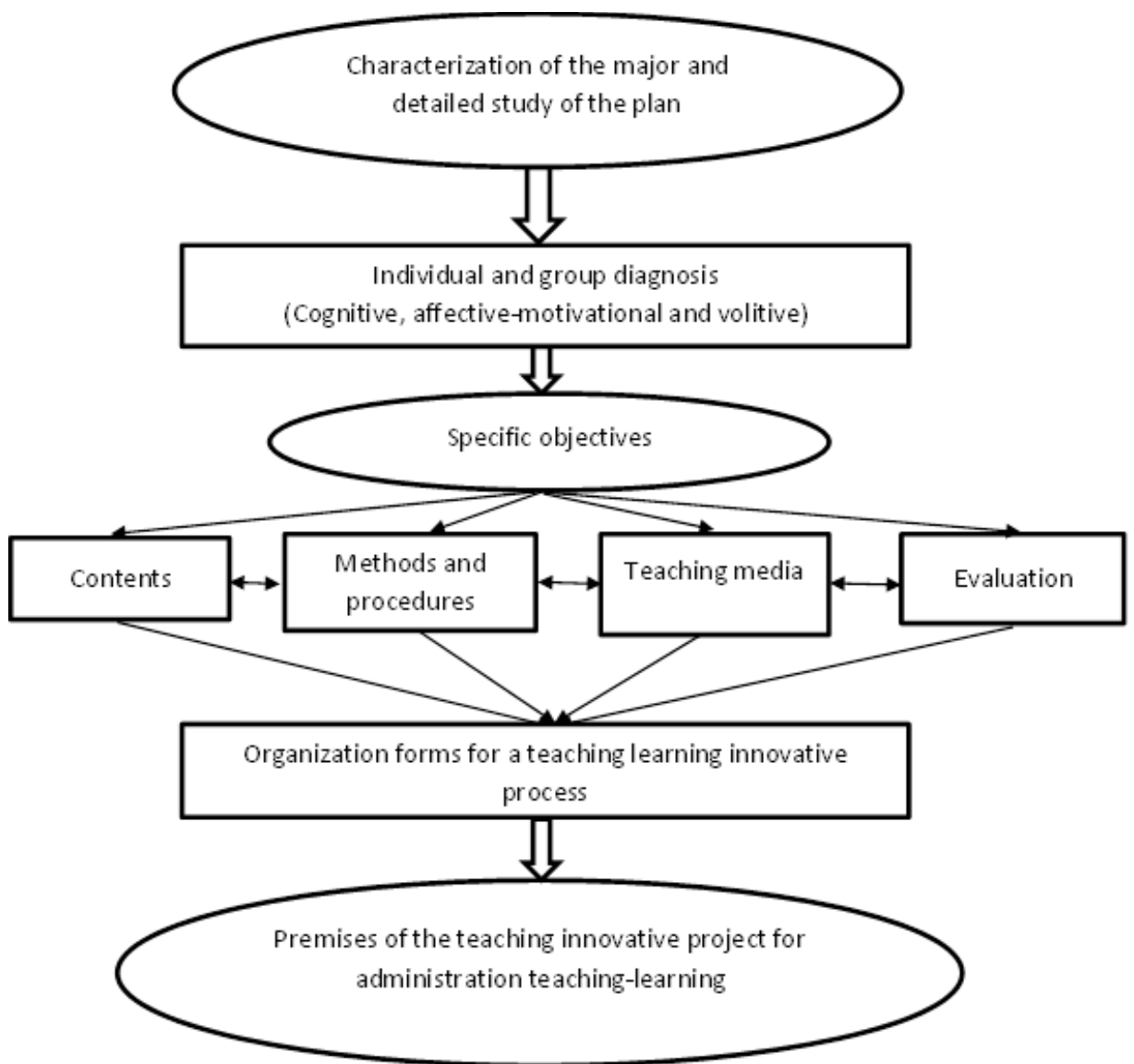

Figure 1:- Teaching-educative innovation project.

The main results obtained in the implementation phase of the project are presented in the order of the developed model.

The following objectives were identified:

1. To explain the relevant aspects that conform administration making it different to other social disciplines and analyzing different conceptions provided by different authors.

2. To identify enterprise as an application field of administration, recognizing the importance of its growing and economic development.

3. To characterize the planning process, its types and elements as a way of determining the plans and programs applied to several types of social organisms, with the aim of facilitating the fulfillment of organizational objectives.

4. To characterize the organization process and its contribution to order and efficient coordination in all kinds of enterprises, interpreting the different types of organizational structure and apply the departmental process as a procedure in enterprise organization.

5. Characterize management as stage of the administrative process based on their characteristics and integration of management skills needed to implement the strategy effectively, efficiently and effectively, explaining the importance and the work of the leadership, motivation, communication and leadership in the decision-making process in organizations.

6. To characterize the control process, its forms and types to monitor the results achieved in enterprises and adopt the pertinent corrective measures.

General competence of the subject: to form a knowledge system, skills and values (competences) that allow to solve enterprises problems applying the stages of administrative process (AP) and the adequate tools for decision making.

Specific subject competences: 
Diagnose business problems of the community, promoting innovation and entrepreneurship for personal and collective development of citizens.

Increasing training and development of management skills and promote entrepreneurship for the development of the productive matrix.

The contents determined in correspondence with the objectives and governing category of teaching-learning process is:

Part I:General theory of administration, administration and organizations, the enterprise, the enterprisers and economic development.

Part II: Administrative process, planning, organization, management, control.

The objectives and content determined methods and procedures, teaching aids, evaluation and forms of organization for innovative teaching learning process. Consistent with the operational definition developed by the authors for research and assumed premises.

This enabled the integration of university substantive processes (teaching, research and community outreach) in the project of teaching and educational innovation developed from the subject, which is exemplified below through research to medium cycle and cycle end developed by students who presented below.

Structure of research work of mid cycle:

1. Introduction. Reflect the importance of work and define the objectives.

2. Development. Theoretical referential frame of research

3. Administrative diagnosis: enterprise characterization, mission, vision, enterprise philosophy and organizational values, services and products to offer, markets, organizational structure, departments and functional areas, workers distribution, functions, salaries, assess compliance of the fields of study of administration as a discipline, administrative roles, efficiency, efficacy and effectiveness assessment, how they stimulate innovation and entrepreneur spirit, enterprise classification according to the economic theory, size, sector and origin of its capital and resources, to identify the shareholders and stakeholders, fulfillment and definition of the stages of the planning process, matrix FODA or DAFO elaboration. Definition of its strategies, actions plan presentation, derived from the enterprise diagnosis.

4. Conclusions and bibliography according to APA norm.

Orientations about the research work in the End of cycle are can be seen in the work structure:

Introduction and work objective.

Work structure

1. Introduction and work objective.

2. Development of the research. Brief theoretical referentialframe.

2.1 Administrative diagnosis. Organization, enterprise characterization, enterprise object, and organizational structure for the fulfillment of functions, organization type: by product -markets, matrix, functional, client, to expose and evaluate the real functioning structure. Precise management levels. To present the organization chart, evaluate the horizontality or verticality of the structure, if executive management line is respected, if in the enterprise there are chiefs without subordinates and if each worker answers for the fulfillment of its duties, tasks and missions of just one head.

2.2. Management, execution, leadership or heading: to characterize and evaluate leadership styles.

$¿$ Which is the predominant style? Autocratic-Democratic-Liberal

¿Are boss decisions made taking into consideration other opinions? Yes-No-How?

¿Are workers' criteria put into practice whenever possible? Yes-No-How?

¿Which are the mechanisms and what methods are used to reach the workers' motivation? Assess them as: G-R-B. Support

¿Are main work (and no work) necessities known? Do you know the degree of satisfaction of these main necessities (high-mid-low) Yes-No-How?

Evaluation of the degree of participation of workers in decision making and the way it is achieved. High-Mid-Low. Support 
¿Are the workers' problems solved? Yes-No-How?

To analyze the styles, methods and mechanisms used to solve the problems and insufficiencies present in the enterprise. G-R-B. Support

¿Are the existent techniques used for problems negotiation? Yes-No-How?

Assessment of workers' promotion policy.G-R-B. Support

Characterize the coordination relations established between the general director and other bosses. G-R-B. Support

¿Is the general director right about the objectives to reach in the enterprise? And other bosses? Yes-No-How?

¿Does the boss know how to choose his collaborators? Yes-No-How?

¿Does the boss know how to delegate, does he delegate in practice? Yes-No-How?

To assess the way communication takes place in the Enterprise. G-R-B. Support

¿To determine the barriers of communication in the enterprise. Psychological. Yes-No-Which?, Semantic. Yes-No-

Which,Administrative. Yes-No-Which.Physiological. Yes-No-Which?, Physical. Yes-No-Which?

To evaluate leadership and main leadership styles. G-R-B

2.3. Control: To define the methods and forms of control used in the enterprise, to assess if as method of direction, control and assessment extend to all links of enterprise or if they stay only at the level of direction.

3. Conclusions of work and bibliography, according to APA norm.

Then the quantitative results of the implementation of the innovation project in each cycle are set.

Table 1:- Mid cycle evaluations. Students of Administration I.

\begin{tabular}{|c|c|c|c|c|c|}
\hline \multicolumn{2}{|c|}{ Research project 10 points } & \multicolumn{2}{|c|}{$\begin{array}{c}\text { Classroom evaluation activities } 20 \\
\text { points }\end{array}$} & \multicolumn{2}{|c|}{ Written exam 20 points } \\
\hline $\begin{array}{l}\text { Marks obtained } \\
\quad(10 \text { point })\end{array}$ & $\begin{array}{l}\text { Quantity of } \\
\text { students }\end{array}$ & $\begin{array}{l}\text { Marks obtained } \\
\quad(20 \text { point })\end{array}$ & $\begin{array}{l}\text { Quantity of } \\
\text { students }\end{array}$ & $\begin{array}{l}\text { Marks obtained } \\
\text { (20 point) }\end{array}$ & $\begin{array}{l}\text { Quantity of } \\
\text { students }\end{array}$ \\
\hline $5 / 10$ & 1 & $18 / 20$ & 8 & $8 / 20$ & 1 \\
\hline $6 / 10$ & 6 & $19 / 20$ & 4 & $10 / 20$ & 3 \\
\hline $7 / 10$ & 5 & $20 / 20$ & 4 & $12 / 20$ & 3 \\
\hline $8 / 10$ & 1 & Total & 16 & $14 / 20$ & 4 \\
\hline $9 / 10$ & 2 & & & $16 / 20$ & 2 \\
\hline Not present & 1 & & & $18 / 20$ & 1 \\
\hline Total & 16 & & & $20 / 20$ & 1 \\
\hline & & & & Not present & 1 \\
\hline & & & & Total & 16 \\
\hline
\end{tabular}

Source: Universidad Técnica Manabí

It can be seen that the results were satisfactory in different aspects considered to be above the minimum acceptable knowledge above $50 \%$.

Table 2:- Final cycle evaluations Students of Administration I.

\begin{tabular}{|c|c|c|c|c|c|}
\hline \multicolumn{2}{|c|}{ Research project 10 points } & \multicolumn{2}{c|}{$\begin{array}{c}\text { Classroom evaluation activities 20 } \\
\text { points }\end{array}$} & \multicolumn{2}{c|}{ Written exam 20 points } \\
\hline $\begin{array}{c}\text { Marks obtained } \\
(10 \text { point })\end{array}$ & $\begin{array}{c}\text { Quantity of } \\
\text { students }\end{array}$ & $\begin{array}{c}\text { Marks obtained } \\
(20 \text { point })\end{array}$ & $\begin{array}{c}\text { Quantity of } \\
\text { students }\end{array}$ & $\begin{array}{c}\text { Marks obtained } \\
(20 \text { point })\end{array}$ & $\begin{array}{c}\text { Quantity of } \\
\text { students }\end{array}$ \\
\hline $0 / 10$ & 3 (did not hand in $)$ & $18 / 20$ & 4 & $10 / 20$ & 2 \\
\hline $7 / 10$ & 4 & $19 / 20$ & 11 & $12 / 20$ & 2 \\
\hline $10 / 10$ & 8 & Total & 15 & $14 / 20$ & 2 \\
\hline Total & 15 & & & $16 / 20$ & 4 \\
\hline & & & & $18 / 20$ & 5 \\
\hline & & & & Total & 15 \\
\hline
\end{tabular}

Source: Universidad Técnica Manabí 
Table 3:- Final cycle evaluations Students of Administration.

\begin{tabular}{|l|c|}
\hline Marks obtained & Quantity of students \\
\hline From $70-79$ & 6 \\
\hline From $80-89$ & 8 \\
\hline From $90-100$ & 1 \\
\hline Total & 15 \\
\hline
\end{tabular}

Source: Universidad Técnica Manabí

It is noted that the results of most students are above $70 \%$ in the final cycle, which favorably influenced the final evaluations, where $100 \%$ of students are located from $70 \%$ scores.

In the qualitative assessments made by students and teachers they were offered favorable project criteria of educational teaching innovation regarding the following indicators: integrating teaching, research and community outreach, linking theory and practice, active and leading role of students, linking university- company, can integrate the new technologies of Information and Communications Management, development of skills to learn to undertake, consolidation of knowledge of the subject, new methodologies and educational technologies. Learning is facilitated.

\section{Conclusions:-}

The model the teaching innovation project and determined its components and premises. The teaching innovation project generated qualitative and quantitative changes while using innovative technologies and new pedagogical methodologies.

The project achieved favorable results in the learning of students.

\section{Bibliography:-}

1. D’ León, G., Montiel, Y., Velásques, G., Izaguirre, D., \& Araujo, M. (2008). Modelos educativos innovadores: pensamiento crítico y creatividad. Obtenido de http://www.temas-estudio.com/modelos-educativos/

2. García Licona, M. G., \& Sánchez R, P. Y. (Noviembre de 2014). Línea Evolutiva de los Modelos de Innovación Educativa. Obtenido de http://slideplayer.es/slide/6159444/

3. Hernández y Rodríguez, S., \& Palafox D Anda, G. (2012). Administración. España: McGraw-Hill. 3era Edición.

4. Marín Idagarra, D. A. (2005). La enseñanza de las teorías de la administración: limitantes epistémicos y posibilidades pedagógicas. INNOVAR. Revista de Ciencias Administrativas y Sociales, vol. 15, núm. 26, 43-58.

5. Palomo Ortíz, M., Pérez Serna, A., Reyes Gómez, E., \& Vargas Mendoza, M. (Julio de 2011). Las Nuevas Tecnologías y la Innovación Curricular. Obtenido de http://es.slideshare.net/ete_archivos/modelos-deinnovacin-educativa?next_slideshow=1

6. Ramírez Navarrete, T. (16 de Febrero de 2011). Investigación e innovación educativa. Obtenido de http://es.slideshare.net/tania_ramirez/investigacin-e-innovacion-educativa

7. UNESCO. (9 de Octubre de 1998). Declaración mundial sobre la educación superior en el siglo XXI: visión y acción. Obtenido de http://www.unesco.org/education/educprog/wche/declaration_spa.htm

8. Universia España. (2015). Innovación docente. Obtenido de http://profesores.universia.es/docencia/innovaciondocente/

9. Willians, C. (2013). Administración. México: Cengage Learning. 